\title{
Cardio Protective Effect of Solanum nigrum Linn. in Isoproterenol Induced Myocardial Infarction in Rat
}

\author{
Sameer Amjad Shaik ${ }^{1}$, Shivaprasad Huded ${ }^{1}$, Asra Fathima ${ }^{2}$, Preran K. ${ }^{3}$, \\ Syeda Juveriya Fathima ${ }^{2}$ and Farhath Khanum ${ }^{2^{*}}$ \\ ${ }^{1}$ Department of Dravyaguna, JSS Ayurveda Medical College, Mysore, Karnataka, India \\ ${ }^{2}$ Biochemistry and Nanosciences Discipline, Defense Food Research Laboratory, Siddhartha Nagar, \\ Mysore, Karnataka-570 011, India \\ ${ }^{3}$ Department of Pharmacology, JSS College of Pharmacy, Mysore, Karnataka, India
}

\begin{tabular}{|c|c|}
\hline Abstract & Article Information \\
\hline \multirow{12}{*}{$\begin{array}{l}\text { Myocardial infarction is one of the highest confronting metabolic syndromes which cause } \\
\text { morbidity and mortality across the world. Recently, the renewed interests in medicinal } \\
\text { plants have certain preventive action in treatment of cardiovascular disorder. The aim of } \\
\text { the study was to investigate the cardio protective effects of Solanum nigrum Linn (hydro } \\
\text { alcoholic extract) in isoproterenol induced myocardial infarction. The extracts were } \\
\text { investigated for in vivo cardio protective activity; the rats were pre treated with hydro } \\
\text { alcoholic extract ( } 75 \mathrm{mg}, 150 \mathrm{mg} \text { and } 300 \mathrm{mg} \text { ) for a period of } 21 \text { days. Standard drug } \\
\text { (carvedilol - } 2 \mathrm{mg} / \mathrm{kg} \text { ) was used to compare the results with various parameters like } \\
\text { bodyweight, ECG, heart weight, serum parameters and enzyme estimation. The rats fed } \\
\text { with extracts showed dose dependent cardio protective activity. Isoproterenol treated } \\
\text { animals showed a marked increase in serum marker enzymes such as CK- MB, LDH, } \\
\text { cholesterol, triglycerides, SGOT, SGPT. It was also observed that there was substantial } \\
\text { increase in heart and body weight along with endogenous enzyme levels of LPO. There } \\
\text { was significant decrease in levels of SOD, CAT and GSH. Treatment group significantly } \\
\text { reduced the effects of isoproterenol induced myocardial infarction. Solanum nigrum hydro } \\
\text { alcoholic extract treated groups possess cardio protective effect against isoproterenol } \\
\text { induced myocardial infarction. }\end{array}$} & Article History: \\
\hline & Received : 01-11-2015 \\
\hline & Revised \\
\hline & Accepted : 29-12-2015 \\
\hline & Keywords: \\
\hline & Cardio protective \\
\hline & Isoproterenol \\
\hline & Solanum nigrum \\
\hline & Antioxidant \\
\hline & ${ }^{*}$ Corresponding Author: \\
\hline & Farhath Khanum \\
\hline & E-mail: \\
\hline Copyright@2015 STAR Journal, Wollega University. All Rights Reserved. & farhathkhanum@gmail.com \\
\hline
\end{tabular}

\section{INTRODUCTION}

Ahita ahara vihara and manasika bhavas (Agnivesa, 2004; Sushrutha, 2012; Vagbhata, 1999; Vagbhata, 2011a) commonly leads to diseases and disorders. The science of Ayurveda plays an important role in maintenance of health of an individual. In today's fast paced life, the lifestyles of the people have undergone a major shift. These changes have an impact on the health of individuals. Earlier epidemic diseases caused more human fatalities, but in the present scenario, coronary heart disease is the principle cause for human mortality. The people being afflicted with cardio vascular diseases, hypertension, diabetes mellitus etc., are increasing day by day. It is reported that CVD is the major cause of death globally. In 2012, CVD alone accounted for 17.5 million deaths worldwide, out of which 7.4 million were due to CHD and 6.7 million were due to stroke. $82 \%$ of these deaths occur in developing and under developed countries. By the end of 2030, the number is expected to increase up to 23.3 million deaths globally. Accordingly it is found to affect the urban population more than the rural population. This shows that the lifestyle is a major factor for the onset of CHD. Effective screening, regular evaluation and timely management strategies for $\mathrm{CHD}$ ( http://www.who.int/mediacentre/factsheets/fs317/en/) are not well established in developing countries like India, but are fully implemented in developed countries. CHD can be prevented by addressing risk factors such as smoking, lack of physical activity, unhealthy diet leading to obesity, hypertension, and diabetes and so on.

Ayurvedic sciences have similar principles where changes in the lifestyle are advised by explaining the Dinacharyas and Rtucharyas. Reference of Hrudroga and its treatment is found in treatise (Vagbhata, 1999). Hrudya is one among such pharmacological activity. This can be elicited from Hrudyadashemani (Agnivesa, 2004), Parushakadi gana (Sushrutha, 2012) and Vidaryadi gana (Vagbhata, 2011a) by Acharya Charaka, Sushrutha and Vagbhata respectively. Thus, Hrud rogas were prevalent even in those times and were treated successfully. Acharya Charaka and Vagbhata considered Hrudaya as the most important among the dashapranayatanas. They described the Prana to be residing in the Hrudaya. This suggests the importance attached to Hrudaya and Hrud roga by the Acharyas (Vagbhata, 2011b). 
Sameer Amjad Shaik et alo,

Solanum nigrum, an ayurvedic herb is consumed in day to day life. It is highlighted as Hrudya, Hrudroganashini by nighantu karas and is also used as bhavana dravya in Hrudayarnava Rasa (Dundukanath, 2006), Shankara Vati (Govinda, 2009) which are indicated in hrudroga. The aim of the study was to evaluate the cardio protective activity of Solanum nigrum by assessing various parameters.

\section{MATERIALS AND METHODS}

Plant Material and Preparation of Hydro Alcoholic Extract

Fresh plant of Solanum nigrum was procured from local market, Mysore and was authenticated by Dr. Nagamani, Professor and HOD, Deparment of Dravyaguna, Ayurveda Medical College, Mysore. Fresh plant material was washed, chopped and shade dried at room temperature. The dried powder was then soaked in ethanol and distilled water in the ratio 7:3 for 48 hours at room temperature (dark) with constant shaking using orbitek shaker. Later the filtrate was evaporated using rotary evaporator (Heidolph, Germany) at $40^{\circ} \mathrm{C}$ to obtain a dark green extract of Solanum nigrum.

\section{In Vivo Studies}

The 36 healthy male Wistar albino rats $(200-250 \mathrm{~g})$ were obtained from the central animal house, Defence Food Research Laboratory, Mysore. The experimental animals were maintained under good hygienic conditions with standard temperature $\left(22 \pm 2{ }^{\circ} \mathrm{C}\right)$ and free access to commercial pellet diet and water, ad libitum. All the experiments were performed in accordance with the IAEC constituted as per the directions of CPSCEA India (Approval No. DFRL/IAEC/01/2015 dated $27^{\text {th }}$ April 2015). Limit test was carried out in accordance to the OECD guideline (No. 423) for HAE of Solanum nigrum at $2000 \mathrm{mg} / \mathrm{kg}$. The animals were divided into 6 groups of 6 each. The animals in the group 1 were treated as control. No pre treatment was given to the animals in group 2. The animals in group 3 were fed with standard drug ie. carvedilol $(2 \mathrm{mg} / \mathrm{kg}$ ) (Kenichi Watanabe et al., 2000). As the rat effective dosage of Solanum nigrum extract was $65.36 \mathrm{mg} / \mathrm{kg}$ (by rat dosage conversion), the animals in the group 4, 5 and 6 were fed with different concentrations of Solanum nigrum extract such as $75 \mathrm{mg}, 150 \mathrm{mg}$ and $300 \mathrm{mg}$ per $\mathrm{kg}$ body weight respectively. All the groups were subcutaneously injected with isoproterenol (85mg/kg) (Panda et al., 2008) on $22^{\text {nd }} \& 23^{\text {rd }}$ day, except for group 1. Symptoms and mortality in each group were recorded and compared with that of group 2. The rats were sacrificed after 48 hours of the first isoproterenol administration, and autopsied. The serum and tissues samples were subjected for further biochemical analysis.

Determination of Electrocardiography and Heart Rate

After 12 hours of the second dosage (isoproterenol), needle electrodes were placed to record the ECG and heart rate (Powerlab 8/35, AD Instruments, Australia) under anaesthetic conditions induced by a combination of Ketamine hydrochloride $(75 \mathrm{mg} / \mathrm{kg}$ i.p) and xylazine $(8 \mathrm{mg} / \mathrm{kg}$ i.p) in the experimental animals. The data was acquired using Labchart Pro (AD Instruments, Australia).

\section{Estimation of Biochemical Parameters}

On the $24^{\text {th }}$ day, the blood was collected from the retro-orbital plexus from the inner canthus of the eye under light ether anaesthesia using capillary tubes. The blood was centrifuged (Table top refrigerated high speed
Sci. Technol. Arts Res. J., Oct-Dec 2015, 4(4): 77-82

centrifuge 3-30K, Sigma, Germany) at 3000rpm for $10 \mathrm{~min}$ at $4^{\circ} \mathrm{C}$. The collected serum samples were used to analyze biochemical parameters such as CKMB, LDH, cholesterol, triglycerides, SGOT, SGPT, Trop -T using respective biochemical kits.

\section{Estimation of Antioxidant Activity}

The rat heart was washed in ice cold saline and weighed $(1 \mathrm{~g}) .10 \%$ homogenate was prepared in $0.1 \mathrm{M}$ Tris-buffer, $\mathrm{pH}$ 7.4. The homogenate was then centrifuged at $10000 \mathrm{~g}$ for $20 \mathrm{~min}$. The supernatant was used to measure the enzyme activities such as lipid peroxidation (Young et al., 2013), superoxide dismutase (Sandra et al., 2013), catalase (Sandra et al., 2013) and reduced Glutathione (Shakti et al., 2012).

\section{Histopathological Examination}

The rat heart were excised and immediately fixed with $10 \%$ neutral formalin. The fixed tissue was then dehydrated with alcohol prior to embedding in paraffin. The ventricular mass from the heart tissue was then sectioned serially with a thickness of $5 \mu \mathrm{m}$ from apex to base. These sections were stained with hematoxyllin and eosin stain and examined under light microscope.

\section{Statistical Analysis}

Results were expressed as mean \pm SEM using GraphPad Prism 6. Statistical significance was assessed using One Way Analysis of Variance (ANOVA) followed by Tukey's multiple comparison test. $p<0.05$ was considered significant. Chi square test was used to analyze the quantitative data (Trop $\mathrm{T}$ ) with significance value of $p<0.05$

\section{RESULTS AND DISCUSSION}

\section{Determination of Body Weight and Heart Weight}

It was observed that the body weight in the isoproterenol group was significantly increased when compared to normal group, whereas in treatment groups there was a significant decrease (Table 1). Carvedilol administered group showed weight gain which may be attributed as a side effect of carvedilol. It was observed that there was increase in the heart weight of isoproterenol treated group; while there was marked decrease in the Solanum nigrum extract treated groups. Standard group showed better protection due to its $\beta$ adrenergic receptor binding activity (https://en.wikipedia.org/wiki/Carvedilol).

Table 1: Effect standard drug and extract on heart and body weight of rats

\begin{tabular}{lcc}
\hline Group & $\begin{array}{c}\text { Diff. in Body Wt } \\
\text { gm }\end{array}$ & $\begin{array}{c}\text { Mean Heart Wt } \\
\text { gm }\end{array}$ \\
\hline Normal & $8.67 \pm 1.11$ & $0.71 \pm 0.007$ \\
ISO & $33.67 \pm 2.71^{\mathrm{a}}$ & $1.07 \pm 0.018^{\mathrm{a}}$ \\
STD & $18.16 \pm 3.07$ & $0.70 \pm 0.007^{\mathrm{b}}$ \\
SNE 75 & $5.83 \pm 3.13^{\mathrm{b}}$ & $0.84 \pm 0.012^{\mathrm{abc}}$ \\
SNE 150 & $10.5 \pm 0.99^{\mathrm{b}}$ & $0.82 \pm 0.006^{\mathrm{abc}}$ \\
SNE 300 & $7.16 \pm 2.03^{\mathrm{b}}$ & $0.85 \pm 0.005^{\mathrm{abc}}$ \\
\hline
\end{tabular}

All values are expressed as Mean \pm SEM, $n=6$. Data were analysed by one- way ANOVA followed by post Tukey's multiple comparison test. ( ${ }^{\mathrm{a}} p<0.05$ when compared to Normal; ${ }^{\mathrm{b}} p<0.05$ when compared to Negative control; ${ }^{c} p<0.05$ when compared to Positive control; ${ }^{d} p<0.05$ when compared to SNE $75 ;{ }^{e} p<0.05$ when compared to SNE 150) 
Sameer Amjad Shaik et alo,

Determination of Electrocardiography and Heart Rate

The ST segment, QT interval, RR interval and heart rate of the animals treated with Solanum nigrum extract 75,150 and $300 \mathrm{mg} / \mathrm{kg}$ showed a marked change when compared with isoproterenol treated group. Changes in these parameters indicated that the animals treated with isoproterenol had undergone myocardial infarction and the Solanum nigrum extract administered groups showed remarkable decrease in lowering the ST segment elevation which might indicate reversal of the effects of
Sci. Technol. Arts Res. J., Oct-Dec 2015, 4(4): 77-82

isoproterenol treatment. QT interval and heart rate was seen to be markedly increased in isoproterenol treated group, whereas it was decreased in Solanum nigrum extract treated groups due to decrease in myocardial damage. The RR interval was lowered in case of isoproterenol treated group while the Solanum nigrum extract treated groups showed higher interval. The heart rate in carvedilol-administered group showed better results when compared to the Solanum nigrum extract treated groups (Figure 1 and Table 2).

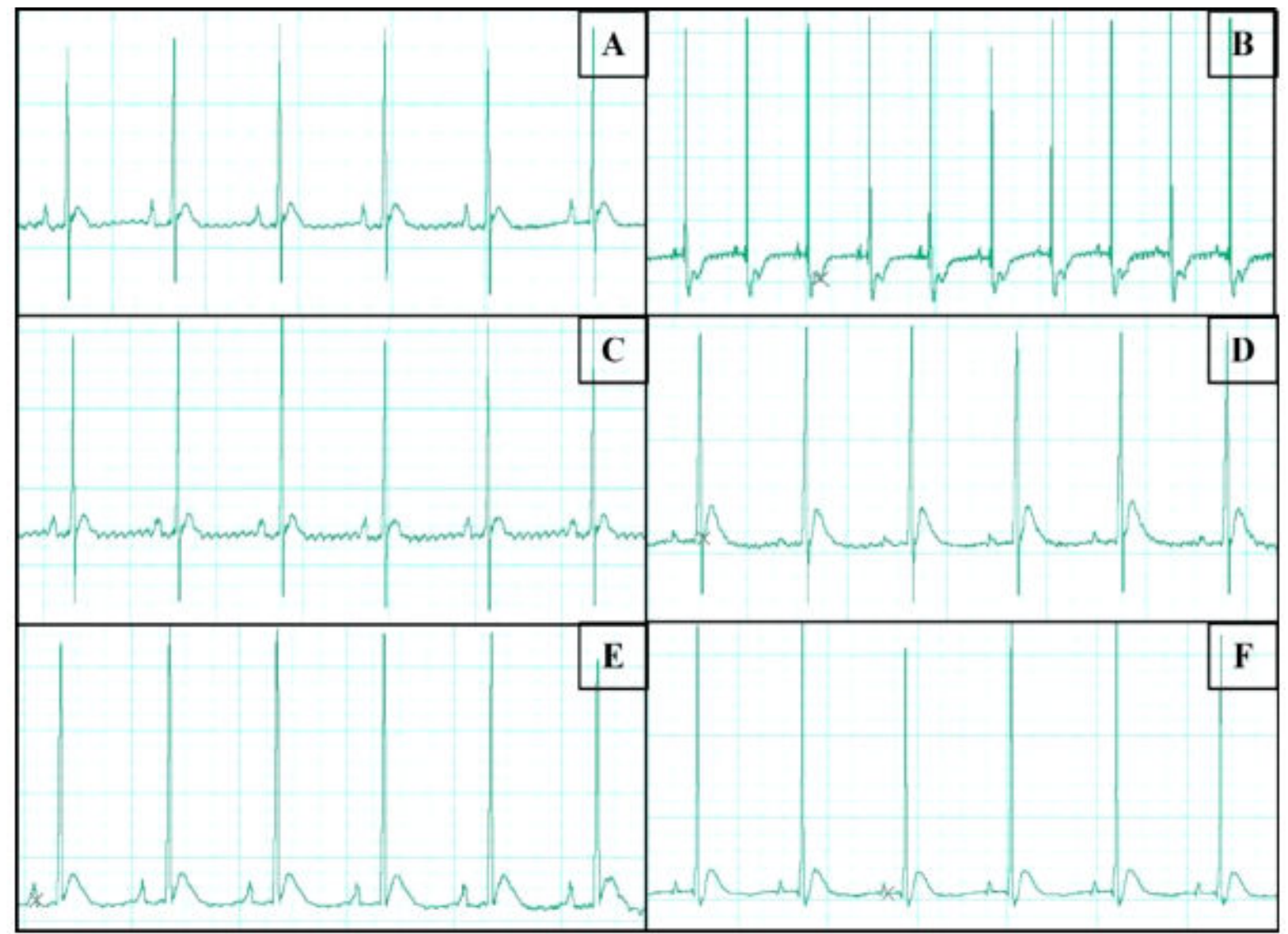

(A) ECG - Control group; (B) ECG - Isoproterenol group; (C) ECG - Standard group; (D) ECG - SNE 75 group;

(E) ECG - SNE 150 group and (F) ECG - SNE 300 group

Figure 1: ECG of control and treated groups

Table 2: Effect standard drug and extract on ECG parameters

\begin{tabular}{ccccc}
\hline Group & ST mV & QT Sec & RR mSec & HR bpm \\
\hline Normal & $0.22 \pm 0.01$ & $0.11 \pm 0.012$ & $0.16 \pm 0.002$ & $358.16 \pm 6.5$ \\
ISO & $-0.08 \pm 0.001^{\mathrm{a}}$ & $0.16 \pm 0.007$ & $0.11 \pm 0.001^{\mathrm{a}}$ & $528.9 \pm 6.27^{\mathrm{a}}$ \\
STD & $0.15 \pm 0.009^{\mathrm{b}}$ & $0.12 \pm 0.006^{\mathrm{b}}$ & $0.26 \pm 0.004^{\mathrm{ab}}$ & $317.2 \pm 2.38^{\mathrm{ab}}$ \\
SNE 75 & $0.04 \pm 0.003^{\mathrm{abc}}$ & $0.12 \pm 0.006$ & $0.19 \pm 0.002^{\mathrm{abc}}$ & $406.06 \pm 4.33^{\mathrm{abc}}$ \\
SNE 150 & $0.02 \pm 0.002^{\mathrm{abcd}}$ & $0.10 \pm 0.012$ & $0.20 \pm 0.002^{\mathrm{abc}}$ & $387.81 \pm 2.86^{\mathrm{abc}}$ \\
SNE 300 & $0.07 \pm 0.003^{\mathrm{abcde}}$ & $0.10 \pm 0.011^{\mathrm{b}}$ & $0.25 \pm 0.005^{\mathrm{abde}}$ & $339.85 \pm 5.32^{\mathrm{bde}}$ \\
\hline
\end{tabular}

All values are expressed as Mean \pm SEM, $n=6$. Data were analysed by one- way ANOVA followed by post Tukey's multiple comparison test. ( ${ }^{\mathrm{a}} p<0.05$ when compared to Normal; ${ }^{\mathrm{b}} p<0.05$ when compared to Negative control; ${ }^{\mathrm{c}} p<0.05$ when compared to Positive control; ${ }^{\mathrm{d}} p<0.05$ when compared to SNE $75 ;{ }^{\mathrm{e}} p<0.05$ when compared to SNE 150) 
Sameer Amjad Shaik et alo,

\section{Estimation of Biochemical Parameters}

The activities of CK-MB, LDH, cholesterol, triglycerides, SGOT, and SGPT enzymes were found to be significantly increased in isoproterenol treated group when compared to control group (Table 3), whereas no marked change was observed in the cholesterol levels. Standard group exhibited marked improvements in SGOT, SGPT when compared to Solanum nigrum extract treated groups. The treatment groups showed a significant decrease in the enzyme levels when compared to the isoproterenol treated group. It was observed that there was marked decrease in cholesterol and triglycerides levels compared to the control group. Significant increase in the levels of biochemical enzymes in the serum is used as sensitive indicators of cardiac injury. The increase of these biomarkers in the serum suggests leakage of the enzymes from the mitochondria due to myocardial injury.
Sci. Technol. Arts Res. J., Oct-Dec 2015, 4(4): 77-82

Thus, it indicates that the extent of cardiac myocyte injury in pre-treated groups were significantly lesser. Thus, proves the cardio protective activity of the trial drugs.

Troponin $T$ is a cardiac regulatory protein that regulates calcium mediated interaction of muscle filaments, actin and myosin leading to contraction and relaxation of striated muscles. Troponin $T$ is specific to myocardium. Insufficient blood flow and oxygen supply to myocardium causes necrosis and subsequent release of Troponin $\mathrm{T}$ and Troponin I into the bloodstream. Only isoproterenol treated group showed positive for Trop - $T$ in serum, whereas the control, standard and Solanum nigrum extract pre treated groups showed negative results. The increased activity of serum Trop $T$ observed in isoproterenol induced rats was due to cardiac damage induced by isoproterenol.

Table 3: Effect of standard drug and extract on serum parameters

\begin{tabular}{|c|c|c|c|c|c|c|c|}
\hline Group & $\begin{array}{c}\text { CKMB } \\
\text { U/L }\end{array}$ & $\begin{array}{l}\text { LDH } \\
\text { U/L }\end{array}$ & $\begin{array}{c}\text { Cholesterol } \\
\mathrm{mg} / \mathrm{dL}\end{array}$ & $\begin{array}{c}\mathrm{TG} \\
\mathrm{mg} / \mathrm{dL}\end{array}$ & $\begin{array}{c}\text { SGOT } \\
\text { U/L }\end{array}$ & $\begin{array}{c}\text { SGPT } \\
\text { U/L }\end{array}$ & TNT $^{*}$ \\
\hline Normal & $14.71 \pm 0.49$ & $102.55 \pm 0.58$ & $154.58 \pm 2.70$ & $69.18 \pm 0.48$ & $52.55 \pm 0.18$ & $33.79 \pm 0.33$ & 0 \\
\hline ISO & $34.11 \pm 0.55^{\mathrm{a}}$ & $140.66 \pm 0.58^{a}$ & $163.75 \pm 2.62^{a}$ & $75.03 \pm 0.68^{a}$ & $94.23 \pm 0.12^{\mathrm{a}}$ & $56.42 \pm 0.35^{\mathrm{a}}$ & 1 \\
\hline STD & $18.70 \pm 0.62^{\mathrm{ab}}$ & $120.47 \pm 0.85^{\mathrm{ab}}$ & $157.91 \pm 2.70^{b}$ & $67.20 \pm 0.54^{\mathrm{ab}}$ & $55.78 \pm 0.16^{\mathrm{ab}}$ & $37.11 \pm 0.29^{a b}$ & 0 \\
\hline SNE 75 & $27.92 \pm 0.65^{\mathrm{abd}}$ & $136.30 \pm 0.85^{\text {abde }}$ & $153.14 \pm 1.18^{\mathrm{abcd}}$ & $66.55 \pm 0.52^{\text {abcde }}$ & $62.96 \pm 0.20^{\mathrm{abc}}$ & $48.33 \pm 0.31^{\mathrm{bc}}$ & 0 \\
\hline SNE 150 & $23.52 \pm 0.63^{\mathrm{abc}}$ & $131.78 \pm 1.11^{\mathrm{ac}}$ & $152.02 \pm 1.86^{\mathrm{b}}$ & $63.87 \pm 0.64^{\mathrm{ab}}$ & $59.30 \pm 0.27^{\mathrm{abcd}}$ & $45.63 \pm 0.31^{\mathrm{abcd}}$ & 0 \\
\hline SNE 300 & $20.63 \pm 0.70^{\mathrm{abc}}$ & $123.22 \pm 0.76^{\mathrm{abc}}$ & $148.79 \pm 1.13^{b}$ & $60.25 \pm 0.46^{\mathrm{abcd}}$ & $57.73 \pm 0.21^{\mathrm{abcd}}$ & $42.02 \pm 0.26^{\text {abcde }}$ & 0 \\
\hline
\end{tabular}
Where $0=$ Negative, 1 = Positive

All values are expressed as Mean \pm SEM, $n=6$. Data were analysed by one- way ANOVA followed by post Tukey's multiple comparison test $\left({ }^{\mathrm{a}} p<0.05\right.$ when compared to Normal; ${ }^{\mathrm{b}} p<0.05$ when compared to Negative control; ${ }^{\circ} p<0.05$ when compared to Positive control; ${ }^{\mathrm{d}} p<0.05$ when compared to SNE $75 ;{ }^{\mathrm{e}} p<0.05$ when compared to SNE 150 )

\section{Estimation of Antioxidant Activity}

In case of oxidative stress to the myocardial cells by free radicals accumulation of lipid peroxides leads to elevated levels of LPO in the cardiac tissue. There was significant rise in the LPO levels of isoproterenol induced group. The Solanum nigrum extract pretreated groups significantly decreased the LPO levels. The standard carvedilol significantly inhibited the rise of LPO. These findings suggest that the pre-treated groups of trial drugs have a significant effect in inhibition of LPO thereby reducing oxidative stress and maintaining membranal integrity (Table 4).

Isoproterenol induced group showed significant decrease in the SOD, CAT, and GSH levels when compared to the control group. The pre treated groups of Carvedilol, Solanum nigrum extract significantly increased the levels compared to control group. This shows that the trial drug has significant effect on reducing the oxidative stress due to free radicals.

Table 4: Effect on standard drug and extract on antioxidant activity of the enzymes

\begin{tabular}{ccccc}
\hline Group & $\begin{array}{c}\text { Lipid peroxidation } \\
\text { (MDA n moles/mg Protein) }\end{array}$ & $\begin{array}{c}\text { Superxide dismutase } \\
(\mathbf{U} / \mathbf{m g})\end{array}$ & $\begin{array}{c}\text { Catalase } \\
(\mathbf{U} / \mathbf{m g})\end{array}$ & $\begin{array}{c}\text { Glutathione reductase } \\
(\mathbf{U} / \mathbf{m g})\end{array}$ \\
\hline Normal & $0.263 \pm 0.024$ & $10.35 \pm 0.06$ & $6.58 \pm 0.62$ & $6.90 \pm 0.33$ \\
ISO & $0.441 \pm 0.003^{\mathrm{a}}$ & $6.13 \pm 0.01^{\mathrm{a}}$ & $1.31 \pm 0.20^{\mathrm{a}}$ & $3.85 \pm 0.22^{\mathrm{a}}$ \\
STD & $0.360 \pm 0.015^{\mathrm{b}}$ & $9.77 \pm 0.02^{\mathrm{ab}}$ & $8.01 \pm 0.35^{\mathrm{b}}$ & $7.44 \pm 0.07^{\mathrm{b}}$ \\
SNE 150 & $0.414 \pm 0.010^{\mathrm{a}}$ & $7.77 \pm 0.14^{\mathrm{abc}}$ & $4.21 \pm 0.20^{\mathrm{bc}}$ & $6.17 \pm 0.34^{\mathrm{b}}$ \\
SNE 300 & $0.408 \pm 0.002^{\mathrm{ab}}$ & $9.24 \pm 0.20^{\mathrm{abd}}$ & $4.80 \pm 0.33^{\mathrm{bc}}$ & $6.41 \pm 0.03^{\mathrm{bc}}$ \\
SNS & $0.323 \pm 0.004^{\mathrm{bde}}$ & $9.95 \pm 0.14^{\mathrm{bd}}$ & $5.23 \pm 0.35^{\mathrm{bc}}$ & $8.51 \pm 0.23^{\mathrm{bcde}}$ \\
\hline
\end{tabular}

All values are expressed as Mean \pm SEM, $n=6$. Data were analysed by one- way ANOVA followed by post Tukey's multiple comparison test $\left({ }^{\mathrm{a}} p<0.05\right.$ when compared to Normal; ${ }^{\mathrm{b}} p<0.05$ when compared to Negative control; ${ }^{\mathrm{c}} p<0.05$ when compared to Positive control; ${ }^{\mathrm{d}} p<0.05$ when compared to SNE $75 ;{ }^{\mathrm{e}} p<0.05$ when compared to SNE 150)

\section{Histopathological Examination}

Histopathological examination of the control group showed an organized pattern of the myocardial cells with intact nuclei in the tissue and it was observed that the myocardium had normal architecture (Figure 2). The isoproterenol group showed extensive myofibrillar myxoid degeneration and interstitial edema of the myocardial tissue. The Solanum nigrum extract treated groups and the standard drug carvedilol showed that the morphology of the myocardium was essentially within the normal limits with intact nucleus and cardiac architecture with no area of necrosis and cellular infiltration. 


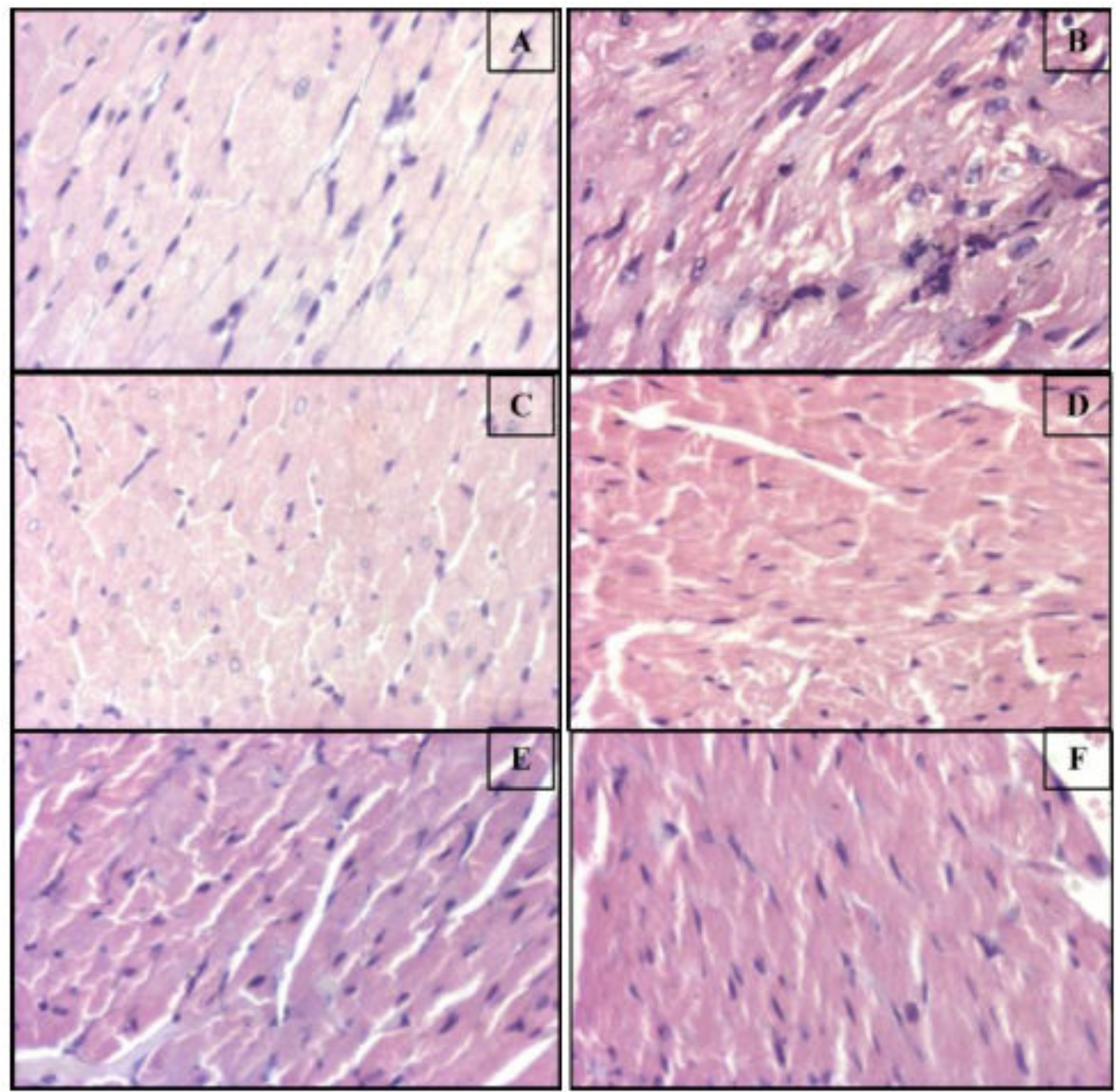

(A) HPE - Control group; (B) HPE - Isoproterenol group; (C) HPE - Standard group; (D) HPE - SNE 75 group; (E) HPE - SNE 150 group and (F) HPE - SNE 300 group

Figure 2: Histopathological images of control and treated groups

\section{CONCLUSIONS}

The results suggested that the parameters such as CKMB, LDH, SGOT, SGPT, Trop - T were reduced to normal values in Solanum nigrum treated group in a dose dependant manner. Histopathological examinations also indicated that the Solanum nigrum treated groups had cytoprotective. Thus, the trial drug, Solanum nigrum can be suitably used as a cardio protective drug.

\section{Conflict of Interest}

None Declared.

\section{Acknowledgement}

The authors thank The Director, DFRL for his constant support and encouragement. The authors also acknowledge The Principal of Dravyaguna, JSSAMC for their support.

\section{REFERENCES}

Agnivesa, Charaka Samhita, (Revised by Charaka and Drdhabala) with Commentary by Pt. Kasinath Shastri and Dr. Gorakhanatha Chaturvedi, Re-print, Varanasi: Chaukhamba Bharati Academy; 2004. p. 738.

Carvedilol [Internet], Wikipedia, [Updated: 2016 April 2; Cited: 2016 April 06], Available from: https://en.wikipedia.org/wiki/Carvedilol
CVD Fact sheet [Internet], Geneva, WHO, [Updated: January 2015; Cited:2016 march 04], Available from: http://www.who.int/mediacentre/factsheets/fs317/en/

Dundukanath, Rasendra Chintamani Sanskrit text with Siddhiprada Hindi vyakhya by Prof. Siddhinandan Mishra, Re-print, Varanas: Chaukhamba Orientalia; 2006. Chapter 9/2; p. 286.

Govinda Dasji Bhishagrathna., Bhaishajya Ratnavali., Edited by B.S Mishra, Commented by Kaviraj Ambiadatta Shastri, Translated by Dr. Kanjiv Lochan, Volume II, Reprint, Varanasi: Chaukambha Sanskrit Sansthan,2009 Chapter 33/52-56; p.447- 448

Kenichi Watanabe., Yoshimi ohta., Mikio Nakazawa., Hiroshi Higuchi., Go Hasegawa., Makoto Naito., Koichi Fuse., Masahiro Ito., Satoru Hirono., Naohito Tanabe., Haruo Hanawa., Kiminori Kato., Makoto Kodama and Yoshifusa Aizawa (2000). Low dose carvedilol inhibits progression of heart failure in rats with dilated cardiomyopathy. British Journal of Pharmacology 130: 1489-1495

Panda, V.S., Naik, S.R. (2008). Cardioprotective activity of Ginkgo biloba Phytosomes in isoproterenolinducedmyocardial necrosis in rats: a biochemical and histoarchitectural evaluation. Experimental Toxicology and Pathology 60: 397-404.

Sandra García-Medina., Judith Angélica Núñez-Betancourt., Alba Lucero García-Medina., Marcela Galar-Martínez. 
Sameer Amjad Shaik et alo,

Nadia Neri-Cruz (2013). The relationship of cytotoxic and genotoxic damage with blood aluminum levels and oxidative stress induced by this metal in common carp (Cyprinus carpio) erythrocytes. Ecotoxicology and Environmental Safety 96: 191-197

Shakti Deep Pachauri., Santoshkumar Tota., Kiran Khandelwal., Verma, P.R.P., Chandishwar Nath., Kashif Hanif., Rakesh Shukla, Saxena, J.K., Anil Kumar Dwivedi (2012). Protective effect of fruits of Morinda citrifolia L. on scopolamine induced memory impairment in mice: A behavioral, biochemical and cerebral blood flow study. Journal of Ethnopharmacology 139: 34-41.

Sushrutha, Sushrutha Samhita, with Nibandhasangraha commentary of Dalhanacharya and Nyayachandrika panjika of Gayadasacharya on Nidanasthana, Edited by yadavji Trikamji Acharya and Narayan Ram Acharya, reprint, Varanasi: Chaukhambha Surbharati Prakashan; 2012. p. 824.
Sci. Technol. Arts Res. J., Oct-Dec 2015, 4(4): 77-82

Vagbhata, Astanga Sangraha, Volume II, Translated by Prof. K. Srikanthamurthy, Second edition, Varanasi: Chaukhamba Orientalia; 1999. p. 627.

Vagbhata, Astanga Hrdaya, with commentaries of Arunadatta and Hemadri, Edited by Pt.Hari Sadasiva Sastri, Re-print, Varanasi: Chaukhambha Surbharati Prakashan; 2011a; p. 956.

Vagbhata, Astanga Hridaya, English translation by Prof. K.R. Srikantha Murthy, 8th Edition, Varansi: Chaukhamba Krisnadas Academy; Sutrasthana, Chapter 15/9, 10; 2011b; p. 201.

Young Woo Lee., Dong Hyun Kim., Su Jin Jeon., Se Jin Park., Jong Min Kim., Jun Man Jung., Hyung Eun Lee., Shin Gil Bae., Hee Kyong Oh., Kun Ho Ho Son., Jong Hoon Ryu. (2013). Neuroprotective effects of salvianolic acid $B$ on an AB25-35 peptide-induced mouse model of Alzheimer's disease. European Journal of Pharmacology 704: 70-77. 